os

\section{THE USE OF ALISMA PLANTAGO IN EPILEPSY.}

BY E. BAINES, Esq., M.R.C.S.

WILlIAM, the son of Serg. T_-, of the Middlesex Rifles, a boy of eight years, has been subject to epileptic fits from a few months after birth. They have increased in frequency and intensity; his mother says that "they average six in a fortnight;" frequent eructations, generally followed by vomiting. Much attention, medical advice, and expense have been lavished on this case without benefit. He was ordered to take four grains of the powder of water plantain twice a day, and to in. crease the dose a grain every third day.

Eighth day.-A slight fit.

Fourteenth day. - An ordinary fit; vomiting has ceased.

Forty-eighth day. - A fit of short duration.

The intervals between the fits have extended to seventy. seven days.

The apparent controlling power of the Alisma Plantago in so little tractable a disease, warrants more extensive trial. The powder is palatable, of a light-brown colour, and, when fresh, has somewhat the odour of cocoa. The best period for collecting the roots is at the end of August, as in mild winters they shoot (probably at the cost of the active principle).

This genus is not new to the British physician, as Miller says of the Alisma Damasonium (Actinocarpus Damasonium of modern botanists) that " if it is wanted as a medicine, it must be gathered in its natural place of growth."

Barnet, August, 1859

\section{NOTES OF THE PRACTICE OF SURGERY IN PARIS.}

BY C. F. MAUNDER, EsQ., F.R.C.S.

\section{HOPITAL DU MIDI.}

MI. BOUCHER.

Fissure of anus treated by forcible dilatation. - The index inger of each hand was introduced into the rectum, and dilata. tion effected by separating the fingers from each other until all resistance on the part of the sphincter ceased. Considerable force was employed.

Subcutaneous uhitlow of index finger. $-\mathrm{M}$. Boucher remarked that in these cases inflammation and its consequences do not extend into the palm of the hand, by reason of the attachment of the skin opposite the metacarpo-phalangeal articulation to the deeper structures, thus forming a natural barrier. Swelling and effusion soon appear on the dorsum of the hand, because, in this region, the fibrous barrier is absent. Again, in flammation and abscess in the tendinous sheath of the fingers do not pass into the palm, because the tendinous sheath ceases at the metacarpo-phalangeal articulation; but, in the thumb, the sheath is continued into the hand, therefore pus may be found in the palm: also, when the interior of the sheath is affected, the finger will be more or less flexed.

Uv: thral fistula. The patient was the subject of three fistulæ, located within half an inch of each other, the most anterior being an inch posterior to the meatus. They are to be treated separately, the most anterior taking precedence. The edges were pared, and brought together after the manner of the quill suture, rolls of adhesive plaster taking the place of quills. No catheter was left in the bladder. The patient was desired to pass his urine through the remaining fistulæ.

\section{A R I B O I S I E R E \\ M. Chassaigrac.}

Cancer of tongue romoved by the écraseur.-One end of the chain was introduced through an opening in the integument just above the hyoid bone, passed through the floor of the mouth between the side of the tongue and the teeth, then over the upper surface of the tongue in front of the epiglottis, and down on the opposite side to the opening in the integument, by which it had entered. The chain was now drawn tight, and shortened to the extent of a link every half minute. Thus the parts from the base of the tongue to the hyoid bone were divided. The tip of the tongue was now removed by the ecraseur, and then, the chain having been readapted, the remaining portion of the organ was removed by dividing its attachments to the gum and lower jaw. The operation lasted thirty-five minutes; not one teaspoonfin of blood was lost, and after the first pang, consequent on drawing tight the chain, the patient did not appear to suffer severely. An easy passage for the chain of the ecraseur had been previously prepared by the introduction and retention of an elastic tube.

Tunour of thigh; excision of five inches of fermur.-DThe patient, a lad about eighteen years of age, was the subject of a tumour of a doubtful nature, occupying the middle of the thigh. M. Chassaignac proposed to explore, and act upon the result of the exploration. A free incision over the outer side of the thigh discovered a fungus hæmatodes, affecting the bone as well as the soft parts. A chain saw passed round the femur at the two points removed five inches of the shaft.

Last year I saw a patient in M. Chassaignac's ward, upon whom he had operated, removing portions of the bone, in a case of ununited fracture. Union had taken place, but at a very awkward angle.

Conservative surgery appears to be making rapid strides but the profession will judge of their value. I will report on the progress of these cases in a future number.

Rue de Rivoli, Paris, August, 1859.

\section{9 第lintor}

OF THE PRACTICE OF

\section{MEDICINE AND SURGERY IN THX}

\section{HOSPITALS OF LONDON.}

Nulla est alia pro certo noscendi via, nisi quam plarinas et morbornm et dissectionum historias, tam aliormm proprias, collectas habere ef inter se comparare.-Mongagri. De Sed, et Cuzs. dForb., lib, 11. Proœmium.

\section{KING'S COLLEGE HOSPITAL.}

FISSURE OF THE SOFT AND IARD PALATE.

(Under the care of Mr. Fergusson.)

Threx examples of fissure of the palate were submitted to the notice of the pupils at King's College Hospital on the 6 th inst. All were not precisely alike in their deformity. In the first patient, a girl about sixteen years old, the cleft extended tbrough the soft and hard palate; that through the former had been operated upon by Mr. Fergusson twelve months ago with success, and on the present occasion the remaining part of the fissure (through the hard palate) was closed - after separating the mucous membrane from the bone-by paring the margins of its centre only, and bringing them together by means of a single interrupted suture. A small surface of mucous membrane thus remains in contact before and behind the suture, which if not united hereafter, can be readily made to do so by the application of nitric acid.

The second instance was also in a girl, aged eighteen years, and differed from the preceding in being a favourable case of simple fissure through the soft palate only. The levator palati muscles of the two sides were divided, and the margins of the fissure were pared, and then brought together by silver wires. Chloroform was not given in these cases. The operation was most satisfactory in both.

A rare and severe example of this deformity was presented in the third patient, a woman about twenty-two years of age, who had a wide gap in the soft and hard palate running through the right nostril and lip, thus presenting a hare-lip in addition. In early life, the latter had been remedied by an operation, but there was still much disfigurement of the features, there being a circular opening leading into the left, and a triangular opening into the right nostril. In this case, too, the fissure in the lip was on the right of the mesial line. The gap in the soft palate was so wide, and the tissues so scanty, that Mr. Fergusson would not advise an operation, as, even in the event of success attending it, a large gap in the hard palate would 